\title{
Kinetics of Serum Amyloid Protein A in Casein-Induced Murine Amyloidosis
}

\author{
Merrill D. Benson, Morton A. Scheinberg, Tsuranobu Shirahama, \\ EDGar S. CATHCART, and MarTha SKINNER \\ From the Arthritis and Connective Tissue Disease Section, Evans Department of Clinical Research, \\ University Hospital, Boston, Massachusetts 02118 and the Division of Rheumatology, Indiana \\ University School of Medicine, Indianapolis, Indiana 46202
}

\begin{abstract}
A B S T R A C T Serum amyloid protein A (SAA), the precursor of secondary amyloid protein, is elevated in chronic diseases which are associated with an increased incidence of amyloid. However, SAA is also elevated in acute bacterial and viral infections and somes forms of cancer. The murine model of caseininduced amyloidosis was studied to determine the relationship between SAA production and amyloid deposition.
\end{abstract}

SAA levels measured by radioimmunoassay were found to be as high as 200 times the normal level in $\mathrm{CBA} / \mathrm{J}$ mice receiving daily parenteral casein. After a single injection of casein the SAA level was elevated by $3 \mathrm{~h}$ and peaked by $12-18 \mathrm{~h}$. Similar levels were found in casein-treated $\mathrm{A} / \mathrm{J}$ mice, a strain less susceptible to the induction of amyloid. Parenterally administered bovine serum albumin, which has low potential for amyloid induction, gave SAA levels in $\mathrm{CBA} / \mathrm{J}$ and $\mathrm{A} / \mathrm{J}$ mice comparable to casein treatment. These data show that, while SAA levels are elevated during chronic antigenic stimulation, there are other factors involved in amyloid formation. These factors may include alterations in the degradation of SAA by the reticuloendothelial system caused by substances such as casein.

Nude (athymic) mice were shown to attain high levels of SAA after receiving casein parenterally. Therefore, thymus-derived lymphocytes are not necessary for the synthesis of SAA.

\section{INTRODUCTION}

Serum amyloid protein A (SAA) ${ }^{1}$ is presumed to be the precursor of the major constituent of amyloid fibrils in secondary amyloidosis (1-5). It is present

Received for publication 23 August 1976.

\footnotetext{
${ }^{1}$ Abbreviations used in this paper: AA, secondary amyloid protein A; BSA, bovine serum albumin; SAA, serum amyloid protein $\mathrm{A}$.
}

in increased concentrations in chronic diseases such as rheumatoid arthritis, tuberculosis, and leprosy, with which an increased incidence of secondary amyloid is associated (5-7), but it has also been shown to be present in all normal human sera in small concentrations and may rise to very high levels during acute inflammatory conditions such as tonsillitis and pneumonia (8). The fact that this serum protein is elevated in diseases which are not associated with an increased incidence of secondary amyloidosis has raised questions about the pathophysiologic mechanisms involved in its synthesis and degradation to give the fibril protein.

In the murine model in which amyloidosis is induced by chronic casein injections, the fibrils have been shown to contain a secondary amyloid protein (AA) which has amino acid analysis and N-terminal amino acid sequence which are comparable to human protein AA $(9,10)$, and in the mouse there is also an SAA protein which is elevated during amyloid induction. In the present study this animal model was used to define the relationship of SAA to the development of amyloid. Serum levels of SAA were measured by radioimmunoassay in $\mathrm{CBA} / \mathrm{J}$ mice during induction of amyloid by casein injection. These levels were compared to levels of SAA protein observed in casein-treated $\mathrm{A} / \mathrm{J}$ mice, a strain less susceptible to the induction of amyloid, and to SAA levels seen after injection of bovine serum albumin (BSA), an antigen which has low potential for inducing amyloid. Because of previous work in which we showed that SAA suppressed in vitro antibody response (11), SAA production was also looked for in the nude mouse treated with casein to see if SAA is a product of thymusderived (T) lymphocytes.

\section{METHODS}

Animals. $\mathrm{CBA} / \mathrm{J}, \mathrm{A} / \mathrm{J}$, and Balb/c mice were obtained from the Jackson Laboratory, Bar Harbor, Maine. Balb/Nu mice 
were obtained from Mammalian Genetics, Animal Production Section, National Cancer Institute, Bethesda, Md. CBA/J mice (8-10 wk) were given 28 daily subcutaneous $0.5-\mathrm{ml}$ injections of $10 \%$ casein. The animals were bled by tail vein at $0,2,6,12,16,21$, and 28 days and sera were pooled. Similarly treated mice received 21 daily injections of casein at which point the injections were stopped and the animals bled at 24,26 , and 28 days after the initiation of casein treatments. $15 \mathrm{~A} / \mathrm{J}$ mice received a similar injection schedule and were bled at comparable intervals.

$\mathrm{CBA} / \mathrm{J}$ and $\mathrm{A} / \mathrm{J}$ mice were also treated with 28 daily $0.5-\mathrm{ml}$ injections of $5 \% \mathrm{BSA}$ and bled at the same intervals.

Three groups of $\mathrm{CBA} / \mathrm{J}$ mice received a single injection of $(a)$ casein, $(b) \mathrm{BSA}$, and $(c)$ sterile saline. Three animals from each group were sacrificed at $3,6,12,18,24,36,48$, and $72 \mathrm{~h}$ and the individual sera were stored frozen. $\mathrm{Balb} / \mathrm{c}$ and $\mathrm{Balb} / \mathrm{Nu}$ mice also were injected with casein and bled at 12,24 , and $48 \mathrm{~h}$.

Antiserum. Amyloid fibrils, isolated from the spleens of amyloidotic CBA/J mice, were solubilized in $4 \mathrm{M}$ guanidine and fractionated on Sephadex G-100 (Pharmacia Fine Chemicals, Inc., Piscataway, N. J.) as previously described (8). Protein AA was isolated as the major retarded fraction and used to produce anti-AA antiserum in New Zealand white rabbits by serial injections of $\mathrm{AA}$ in complete Freund's adjuvant.

Radiolabeling of AA. Murine AA was iodinated by utilizing the methodology of Hunter (12). AA was treated with $0.1 \mathrm{~N} \mathrm{NaOH}$ for $1 \mathrm{~h}$ at $37^{\circ} \mathrm{C}$ followed by neutralization with sulphuric acid. This AA protein was then iodinated with ${ }^{125}$ I (New England Nuclear, Boston, Mass.) by adding 10

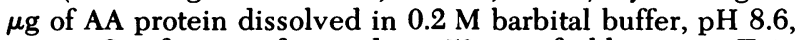
to $1 \mathrm{mCi}$ of carrier-free iodine. $50 \mu \mathrm{g}$ of chloromine $\mathrm{T}$ in $0.1 \mathrm{M}$ barbital buffer, $\mathrm{pH} 8.6$, was added and the oxidation allowed to proceed for $15 \mathrm{~s}$ before addition of $0.8 \mathrm{ml}$ of $1.2 \mathrm{mg} / \mathrm{ml}$ sodium metabisulphite. The labeled AA protein was separated from free iodine on Sephadex G-25 (Pharmacia Fine Chemicals, Inc.) pretreated with $1 \%$ BSA. $0.5-\mathrm{ml}$ fractions were collected and counted in a Packard gamma counter (Packard Instrument Co., Inc., Downers Grove, Ill.) and the most radioactive fraction eluted in the first peak was used for the radioimmunoassay. The radiolabeled AA was stored at $-20^{\circ} \mathrm{C}$ until used.

Radioimmunoassay for SAA. A competitive binding assay was used as described by Yalow and Berson (13). Each tube contained $0.5 \mathrm{ml}$ of rabbit anti-AA antiserum diluted 1:800 in $1 \%$ bovine gamma globulin (Sigma Chemical Co., St. Louis, Mo.) in 0.1 M barbital-buffered saline, $\mathrm{pH} 8.2 .0 .2 \mathrm{ml}$ of serially diluted serum was added and then $0.3 \mathrm{ml}$ of radiolabeled AA protein in $1 \%$ bovine gamma globulin having $20,000 \mathrm{cpm}$ was added. Standard curves were done with serial dilutions of unlabeled AA protein and serial dilutions of a pooled serum standard from CBA/J mice treated with casein. Each tube was mixed on a Vortex mixer (Scientific Industries Inc., Bohemia, N.Y.) and incubated for $2 \mathrm{~h}$ at $37^{\circ} \mathrm{C}$ and overnight at $4^{\circ} \mathrm{C}$. $0.5 \mathrm{ml}$ of $30 \%$ polyethylene glycol (Matheson Gas Products, E. Rutherford, N. J.) (wt/vol) in water was added to each tube with mixing and the tubes were centrifuged at $3,000 \mathrm{rpm}$ for 45 min at $4^{\circ} \mathrm{C}$. Precipitates were counted in a Packard gamma counter. A standard curve for AA protein was obtained by plotting on log-logit paper the percentage of counts per minute precipitated against the amount of AA added to each tube (Fig. 1). A similar standard curve was developed for the pooled CBA/J serum standard. Serum samples to be assayed were diluted $1: 10$ and 1:100. Because of the different molecular weights of the fibril protein and the serum component and, therefore, a possibility of different binding affinities, SAA levels were reported in terms of the pooled

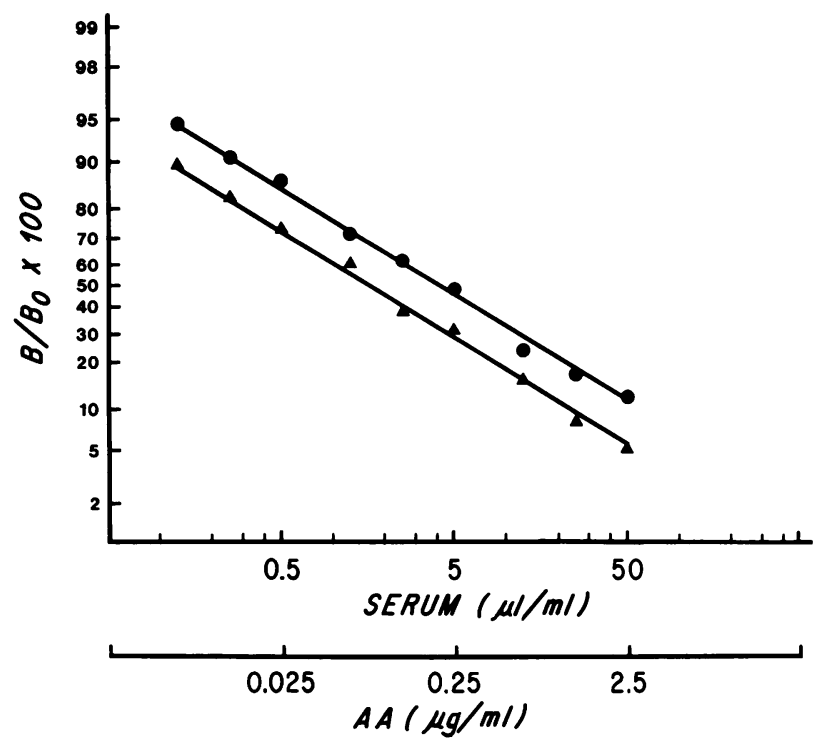

FIgURE 1 Displacement curves of cold murine AA $(\boldsymbol{\Delta}-\boldsymbol{\Delta}-\boldsymbol{\Delta})$ and pooled $\mathrm{CBA} / \mathrm{J}$ serum $(\mathbf{O}-\mathbf{0}-\mathbf{0})$. B, cpm in precipitate; Bo, cpm precipitated by antibody in presence of trace alone.

serum standard and recorded as microliter equivalents per milliliter.

Histology. Frozen and parafin sections of selected spleens representative of the experiment groups were stained with alkaline Congo red and examined by polarization microscopy.

Fractionation of serum. Serum $(5 \mathrm{ml})$ from casein-treated CBA/J mice was made one-third saturated with ammonium sulfate. After $2 \mathrm{~h}$ at room temperature the precipitate was removed by centrifugation and the supernate applied to a G-200 superfine Sephadex column (Pharmacia Fine Chemicals, Inc.) $(2.6 \times 90 \mathrm{~cm}) .3-\mathrm{ml}$ fractions were collected and each fraction was tested for SAA with antiserum to AA by double diffusion in agar. The column was calibrated with human IgG $(145,000)$ and ovalbumin $(46,000)$.

\section{RESULTS}

Antiserum. Two out of five rabbits injected with murine AA produced antisera which gave precipitin lines with isolated $\mathrm{AA}$ and demonstrated the antigenically related serum factor (SAA) by double diffusion in agar. No reaction with human proteins AA or SAA was noted. Antiserum from one rabbit was used to do all radioimmunoassay tests in this study and had a consistent titer of antibody in bleeds taken over several months.

Radioimmunoassay. Iodination of alkali-treated AA protein was done at $\mathrm{pH} 8.6$ as described by Rosenthal and Franklin because of the low solubility of AA protein at physiologic $\mathrm{pH}(8)$. Iodination that utilized chloromine $\mathrm{T}$ as the oxidizing agent yielded up to $80 \%$ precipitation of radiolabeled AA by excess antibody, and the labeled protein was stable over a 2 -wk period when stored at $-20^{\circ} \mathrm{C}$.

A displacement curve that utilized cold AA protein 


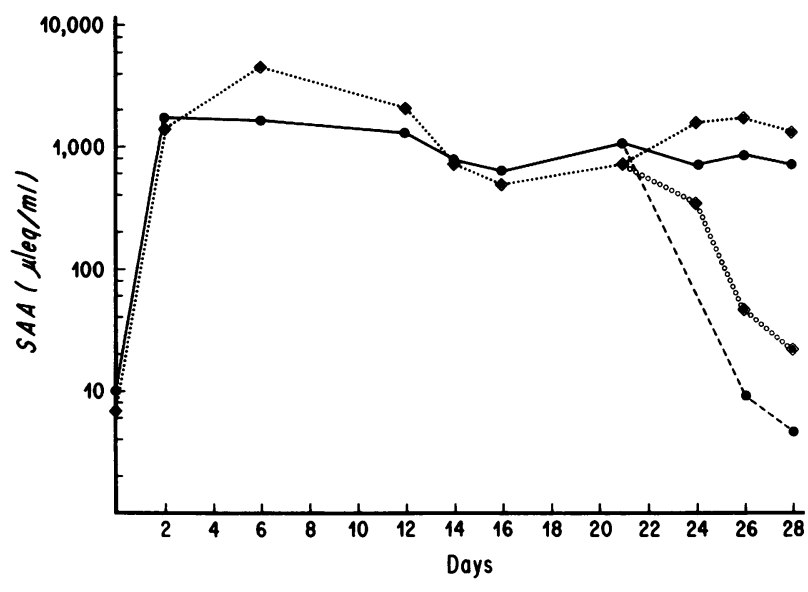

FIgure 2 SAA levels in casein-treated CBA/J $(\diamond \cdots \diamond \diamond)$ and $\mathrm{A} / \mathrm{J}$ mice $(-0-0)$. The decrease in SAA level after cessation of casein at 21 days is indicated by dashed and open circle lines.

was linear from the range of $2,500 \mathrm{ng} / \mathrm{ml}$ down to $25 \mathrm{ng} / \mathrm{ml}$ (Fig. 1). Similarly, a displacement curve that utilized a pooled standard serum derived from CBA/J mice treated with casein was linear from $10 \mu \mathrm{l} / \mathrm{ml}$ down to $0.1 \mu \mathrm{l} / \mathrm{ml}$ when plotted on a log-logit graph. These displacement curves were parallel in several experiments with a slope of approximately -2.5 . Even though this suggested that the degraded tissue AA had an affinity binding similar to SAA, it was decided to use the serum standard as the basis for reporting levels of SAA in the experimental groups. While this does not give an absolute value for levels of SAA, neither would reporting SAA levels in terms of tissue protein AA, since the molecular weights are different.

SAA levels during and after daily casein injections. Normal SAA levels ranged from 5 to $25 \mu \mathrm{leq} /$ $\mathrm{ml}$ for both $\mathrm{CBA} / \mathrm{J}$ and $\mathrm{A} / \mathrm{J}$ mice. After 2 days of daily casein injections, pooled sera from $\mathrm{CBA} / \mathrm{J}$ mice contained 1,400 $\mu \mathrm{leq} / \mathrm{ml}$. The SAA level remained elevated with some fluctuation throughout the course of casein injection (Fig. 2). Discontinuance of casein after 21 days caused a rapid decrease in the SAA level toward normal. By histologic examination spleens from representative mice at 12 days showed that one out of six had small deposits of amyloid, whereas all spleens were positive after 21 injections.

$\mathrm{A} / \mathrm{J}$ mice treated with daily casein injections showed a rise in SAA to $1,700 \mu \mathrm{leq} / \mathrm{ml}$ at 2 days and a course that was not significantly different from the response in CBA/J mice throughout the 28-day experimental period. The SAA level in $\mathrm{A} / \mathrm{J}$ mice also dropped precipitously after cessation of casein treatment (Fig. 2). In contrast to the $\mathrm{CBA} / \mathrm{J}$ mice, none of the $\mathrm{A} / \mathrm{J}$ mice had histologic evidence of splenic amyloid after the 28-day period.
Kinetics of SAA after a single injection of casein. After a single injection of casein in $\mathrm{CBA} / \mathrm{J}$ mice, the mean SAA level was $60 \pm 35 \mu \mathrm{leq} / \mathrm{ml}$ at $3 \mathrm{~h}, 646 \pm 118$ at $6 \mathrm{~h}$, and $1,350 \pm 350$ at $12 \mathrm{~h}$ (Fig. 3). After $18 \mathrm{~h}$ the level of SAA decreased and was $400 \pm 100 \mu \mathrm{leq} /$ $\mathrm{ml}$ by $48 \mathrm{~h}$. Mild elevation of SAA was still present at $72 \mathrm{~h}$. Sterile saline injection failed to give a significant elevation of SAA.

SAA levels in response to BSA. To investigate the importance of the antigen upon SAA production, groups of $\mathrm{CBA} / \mathrm{J}$ and $\mathrm{A} / \mathrm{J}$ mice were injected daily for 28 days with $0.5 \mathrm{ml}$ of $5 \%$ BSA. SAA levels at 3, 8 , $12,14,16,21$, and 28 days were not significantly different from SAA levels in casein-treated animals (Fig. 4). None of the spleens from these animals showed histologic evidence of amyloid deposition. A single injection of BSA gave essentially the same SAA response as a single injection of casein with a peak SAA level of $1,050 \pm 350 \mu \mathrm{leq} / \mathrm{ml}$ at $12 \mathrm{~h}$ (Fig. 3).

SAA levels in nude mice after casein injection. To investigate the possibility that $\mathrm{T}$ lymphocytes are involved in SAA kinetics, athymic nude mice were tested for SAA response. Nude Balb mice ( $8 \mathrm{wk}$ ) were used for this experiment because of unavailability of nude CBA mice. Balb/c (8 wk) mice were used as controls and had a mean normal SAA level of $16 \pm 2 \mu \mathrm{leq} / \mathrm{ml}$. $18 \mathrm{~h}$ after a single casein injection the mean SAA level was $1,400 \pm 58 \mu \mathrm{leq} / \mathrm{ml}$ for Balb/c mice and 1,860 \pm 401 for $\mathrm{Balb} / \mathrm{Nu}$ mice. The peak SAA level was at

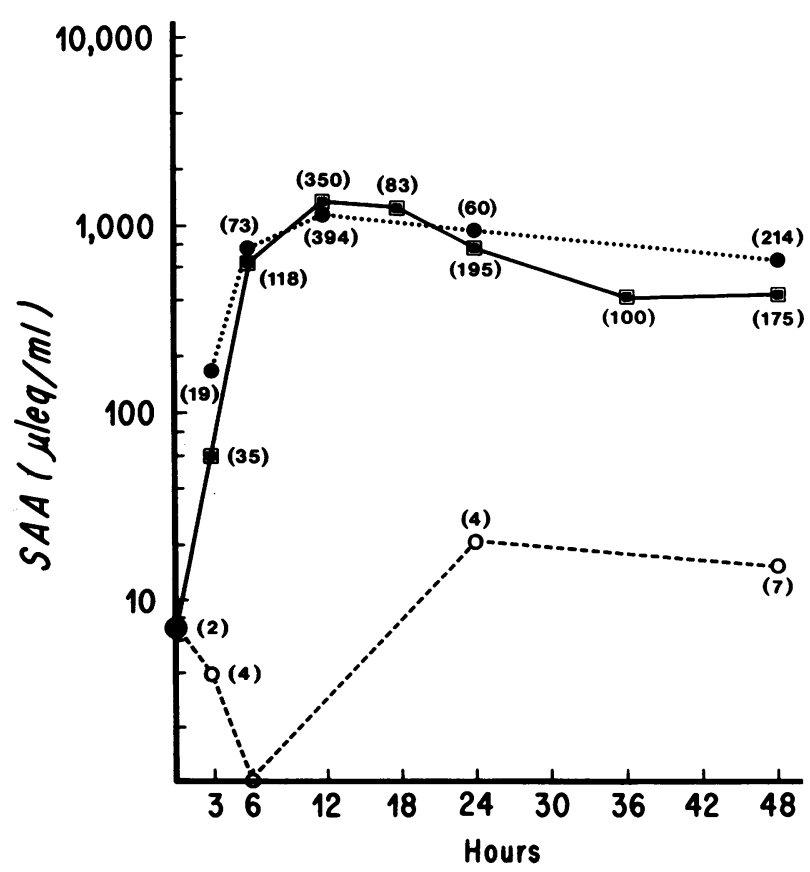

Figure 3 SAA response to a single injection of casein

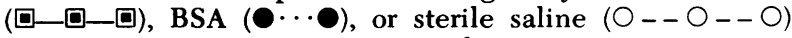
in $\mathrm{CBA} / \mathrm{J}$ mice. SEMs are in parentheses. 


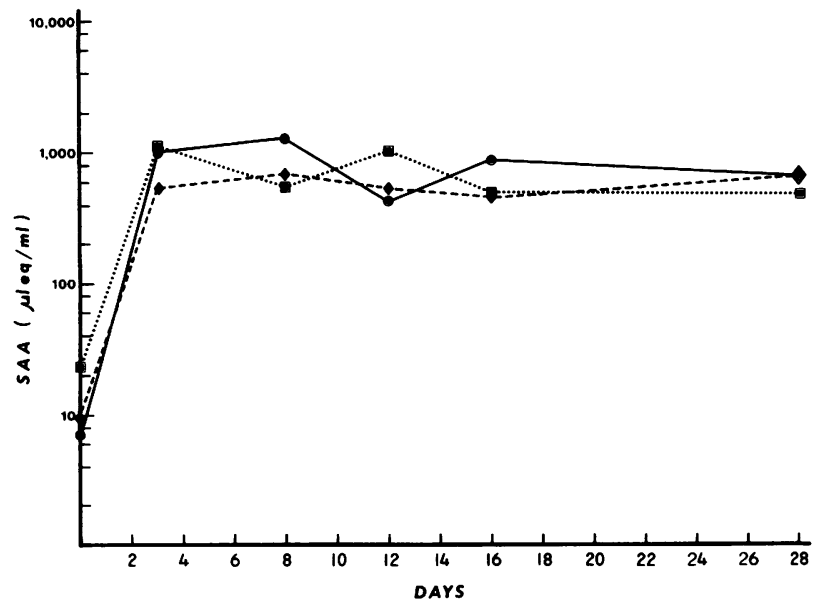

FIGURE 4 SAA levels in BSA-treated CBA/J ( $\square \cdot(\square \cdot \square)$ and $\mathrm{A} / \mathrm{J}(----\downarrow)$ mice compared to casein-treated CBA/J mice (O-

$18-20 \mathrm{~h}$ in $\mathrm{Balb} / \mathrm{Nu}$ mice and significant elevation of SAA was present at $72 \mathrm{~h}$ (Fig. 5).

Fractionation of mouse serum. After precipitation of mouse serum with one-third saturated ammonium sulfate, SAA was detected by double diffusion in agar in the supernate but not in the washed precipitated globulins. On Sephadex G-200 SAA eluted just after the void volume with a partition coefficient between the liquid phase and the gel phase (Kav) slightly less than the Kav of gamma globulin (Fig. 6). This suggested a mol wt of 150,000-200,000 which is somewhat larger than human SAA $(80,000-100,000)$. No smaller sized SAA fractions were found by chromatography in neutral buffer.

\section{DISCUSSION}

Protein SAA is believed to be a serum precursor of the major constituent of secondary amyloid substance (AA). This protein, which was first discovered by its reactivity with antiserum to secondary amyloid protein AA, is an alpha globulin which by gel chromatography has a mol wt of 80,000-100,000 $(5,6)$. Reports of fractionation of human serum under dissociative conditions have described the isolation of a homogeneous substance which has a mol wt of 12,000-14,000 and appears to contain the portion which is homologous with tissue protein AA (14-16). While this suggests that SAA might be attached to a carrier in vivo, the isolation of a tissue AA protein of 25,000 mol wt which degrades under acidic conditions suggests that fractionation of serum in acid conditions may degrade SAA (17).

Thus far all forms of secondary amyloid that have been studied have been composed mainly of protein AA and the serum factor SAA has been described

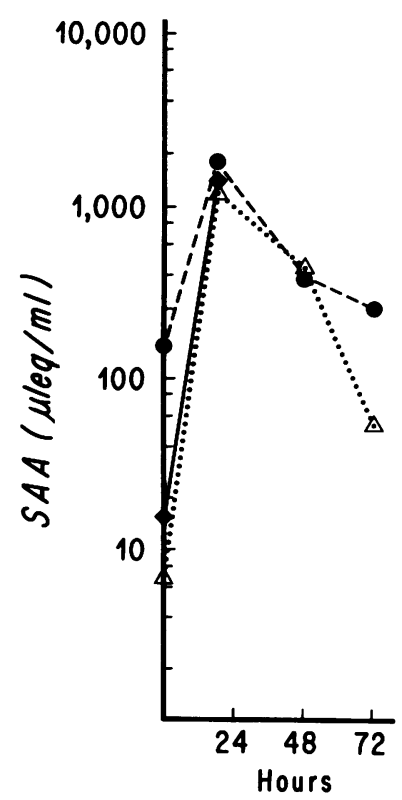

FiguRE 5 SAA response to a single casein injection in Balb/c

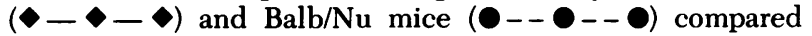
to $\mathrm{CBA} / \mathrm{J}$ response to casein $(\Delta \cdots \Delta \cdots \Delta)$.

for human, mouse, guinea pig, and mink $(5,6,18$, 19). Since casein-induced amyloidosis in the mouse is a readily available model of secondary amyloidosis which has been extensively studied, we used this system to study the kinetics of SAA production after antigenic stimulation and the relationship of SAA levels to amyloid formation. To do this a radioimmunoassay for the serum component was developed.

Antiserum to murine tissue protein AA was used in a competitive binding assay of SAA and it was shown that the tissue and serum proteins have similar binding affinities over the range of concentrations used

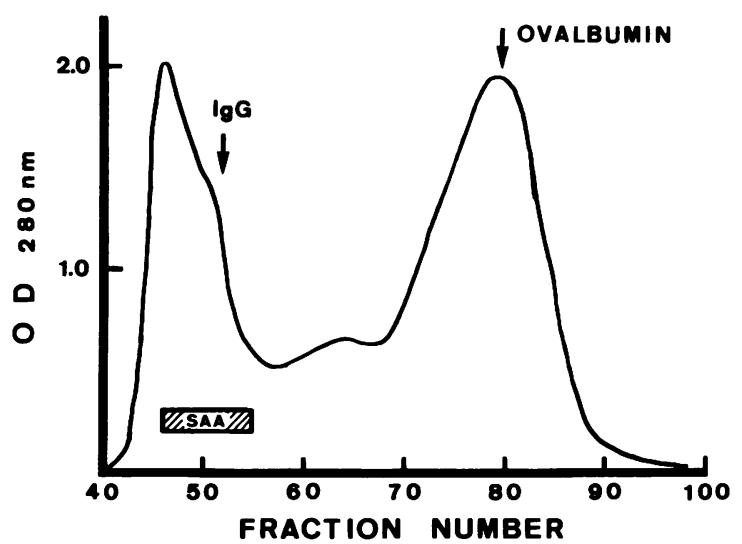

Figure 6 Chromatogram of mouse serum on Sephadex G-200 after precipitation of globulins. SAA is present in fractions slightly retarded on G-200. 
in the assay. The displacement curves of alkali-treated protein $\mathrm{AA}$ and a pooled serum standard from caseintreated CBA/J mice were linear over a range of $50 \mu \mathrm{l} / \mathrm{ml}$ to $0.5 \mu \mathrm{l} / \mathrm{ml}$ of the serum standard and $2,500 \mathrm{ng} / \mathrm{ml}$ to $25 \mathrm{ng} / \mathrm{ml}$ of the tissue AA (Fig. 1). While it was determined that $1 \mu \mathrm{l}$ of standard pooled CBA/J serum was equivalent to approximately $100 \mathrm{ng} / \mathrm{ml}$ of AA protein, it was decided to use the pooled serum as standard and report the assay in microliter equivalents of this standard, since the molecular weight of the serum component is different from that of the tissue protein. The parallelism of the displacement curves for the serum standard and the tissue protein $\mathrm{AA}$ is different from the human system where the displacement curves are not parallel in the range of $25 \mathrm{ng} / \mathrm{ml}$ to $2,500 \mathrm{ng} / \mathrm{ml}$ of human AA protein (15). This difference between the human and murine systems is probably due to differences in antiserum binding affinities.

Treatment of $\mathrm{CBA} / \mathrm{J}$ mice with parenteral casein caused a marked increase in serum SAA levels detectable as early as $3 \mathrm{~h}$ after a single injection and peaking after $12-18 \mathrm{~h}$. This increase was as much as 200-fold. Daily casein injections in the CBA/J mouse caused sustained elevation of SAA persisting through the preamyloid and amyloid phases. Discontinuance of casein injections caused prompt decrease in SAA toward normal levels. If SAA is a precursor of secondary amyloid protein it would be expected to be increased in those situations conducive to the formation of secondary amyloid. However, A/J mice (a strain relatively resistant to the induction of secondary amyloid) also showed marked elevation of SAA after casein treatment. Thus, it is clear that sustained elevation of SAA levels is not the only factor necessary for the deposition of amyloid fibrils. Furthermore, the experiments in which CBA mice were injected with BSA showed that the elevation of SAA protein is not dependent upon the antigen being an "amyloidogenic" substance, since the mice treated with BSA achieved just as high levels of SAA as mice treated with casein. This finding that not only amyloid-producing substances but also nonamyloid-producing substances cause high levels of SAA suggests that there are additional factors involved in the formation and deposition of amyloid protein. N-terminal heterogeneity of some AA proteins (2) and ultrastructural findings supporting amyloid formation in the lysosome-related inclusions in the reticulo-endothelial cells in casein-induced murine amyloidosis support this concept (20). The present findings would tend to support the hypothesis that amyloid-inducing substances such as casein may have both an SAA stimulatory effect and an effect, specific or nonspecific, upon the enzymatic degradative functions of the reticuloendothelial system result- ing in an incomplete degradation and disposal of a metabolic end product.

Anders et al. have recently reported on the SAA response in endotoxin-induced amyloid of mink with SAA levels rising rapidly after injection of endotoxin (19). Using semiquantitative techniques they found a marked decrease in SAA after an initial peak and a subsequent, but lower, peak during the amyloid phase. Two of four control animals injected with sterile saline showed much lower elevations in SAA. In the murine model the marked fluctuations in SAA levels were not seen during induction of amyloidosis. Possible explanations of this difference include species variability, differences in injection schedules (triweekly endotoxin vs. daily casein), and differences in antigens. Also the time of serum collection in relation to antigen injection may be important, since the kinetic studies after a single injection of casein show a rapid drop in SAA after $24 \mathrm{~h}$. Since the pathogenesis and natural history of amyloidosis in the murine model has been more thoroughly studied, correlations between SAA kinetics and immunological abnormalities including marked T-cell impairment (21), polyclonal bone marrow-derived (B)-cell activation (22), and M-cell activation (23) can be made.

We have previously shown that SAA protein in the CBA/J mouse system suppresses the in vitro antibody response of CBA/J spleen cells to sheep erythrocytes (11). We postulated that this substance (SAA) may be a regulator of the immune response to antigenic stimulation. To test the hypothesis that the synthesis of SAA is dependent upon $\mathrm{T}$ lymphocytes, we treated athymic (nude) mice with casein and measured the response of SAA. Because of the unavailability of CBA nude mice, Balb nude mice were used for this experiment. First, it was necessary to show that the Balb mouse was fully as capable of making SAA protein as was the CBA. This was found to be true, and it was also found that the nude Balb mouse was perfectly capable of synthesizing SAA in as high levels as the CBA mouse. These experiments show conclusively that the synthesis of SAA is not dependent upon an intact thymic system.

Whether B lymphocytes are involved in the production of SAA has not been determined. We have described alterations in B-cell functions in spleen cells from amyloid $\mathrm{CBA} / \mathrm{J}$ mice which are not present in casein-treated $\mathrm{A} / \mathrm{J}$ mice and $\mathrm{BSA}$-treated $\mathrm{CBA} / \mathrm{J}$ mice. These include enhancement of response to B-cell mitogens and increased numbers of antibody-producing cells to SIII pneumonococcal polysaccharide and lipoprotein polysaccharide during chronic casein injection $(21,22)$. Similarly, possible production of SAA by the macrophage system warrants further study, since several laboratories have shown that this cell popula- 
tion may play an important role in the regulation of the immune response.

\section{ACKNOWLEDGMENTS}

We thank Barbara Booker and Robert Sturgeon for technical assistance and David Feigenbaum for artistry and photographic assistance.

These investigations were supported by grants from the U. S. Public Health Service, National Institute of Arthritis and Metabolic Diseases (AM-04599 and Tl-AM-5285), from the General Clinical Research Centers Branch of the Division of Research Resources, National Institutes of Health (RR-533), from the Massachusetts Chapter of the Arthritis Foundation, from the Arthritis Foundation, and from the John A. Hartford Foundation.

\section{REFERENCES}

1. Benditt, E. P., N. Eriksen, M. A. Hermodson, and L. H. Ericsson. 1971. The major proteins of human and monkey amyloid substance: Common properties including unusual N-terminal amino acid sequence. FEBS (Fed. Eur. Biochem. Soc.) Lett. 19: 169-173.

2. Levin, M., E. C. Franklin, B. Frangione, and M. Pras. 1972. The amino acid sequence of a major nonimmunoglobulin component of some amyloid fibrils. J. Clin. Invest. 51: 2773-2776.

3. Ein, D., S. Kimura, and G. G. Glenner. 1972. An amyloid fibril protein of unknown origin: partial amino-acid sequence analysis. Biochem. Biophys. Res. Commun. 46: $498-500$.

4. Husby, G., K. Sletten, T. F. Michaelsen, and J. B. Natvig. 1972. Antigenic and chemical characterization of nonimmunoglobulin amyloid proteins. Scand. J. Immunol. 1: 393-400.

5. Benson, M. D., M. Skinner, J. Lian, and A. S. Cohen. 1975. "A" protein of amyloidosis. Isolation of a crossreacting component from serum by affinity chromatography. Arthritis Rheum. 18: 315-322.

6. Levin, M., M. Pras, and E. C. Franklin. 1973. Immunologic studies of the major nonimmunoglobulin protein of amyloid. I. Identification and partial characterization of a related serum component. J. Exp. Med. 138: 373-380.

7. Husby, G., and J. B. Natvig. 1974. A serum component related to nonimmunoglobulin amyloid protein AS, a possible precursor of the fibrils. J. Clin. Invest. 53: 10541061 .

8. Rosenthal, C. J., and E. C. Franklin. 1975. Variation with age and disease of an amyloid A protein-related serum component. J. Clin. Invest. 55: 746-753.

9. Skinner, M., T. Shirahama, M. D. Benson, and A. S. Cohen. 1976. Identification of protein AA and SAA in experimentally induced murine amyloid. Arthritis Rheum. 19: 822-823. (Abstr.)
10. Eriksen, N., L. H. Ericsson, N. Pearsall, D. Lagunoff, and E. P. Benditt. 1976. Mouse amyloid protein AA: Homology with nonimmunoglobulin protein of human and monkey amyloid substance. Proc. Natl. Acad. Sci. U. S. A. 73: $964-967$.

11. Benson, M. D., M. A. Aldo-Benson, T. Shirahama, Y. Borel, and A. S. Cohen. 1975. Suppression of in vitro antibody response by a serum factor (SAA) in experimentally induced amyloidosis. J. Exp. Med. 142: 236241.

12. Hunter, W. M. 1974. Preparation and assessment of radioactive tracers. Br. Med. Bull. 30: 18-23.

13. Yalow, R. S., and S. A. Berson. 1960. Immunoassay of endogenous plasma insulin in man. J. Clin. Invest. 39: 1157-1175.

14. Linke, R. P., J. D. Sipe, P. S. Pollock, T. F. Ignaczak, and G. G. Glenner. 1975. Isolation of a low-molecularweight serum component antigenically related to an amyloid fibril protein of unknown origin.Proc. Natl. Acad. Sci. U. S. A. 72: 1473-1476.

15. Sipe, J. D., T. F. Ignaczak, P. S. Pollock, and G. G. Glenner. 1976. Amyloid fibril protein AA: purification and properties of the antigenically related serum component as determined by solid phase radioimmunoassay. J. Immunol. 116: 1151-1156.

16. Rosenthal, C. J., E. C. Franklin, B. Frangione, and J. Greenspan. 1976. Isolation and partial characterization of SAA - an amyloid-related protein from human serum. J. Immunol. 116: 1415-1418.

17. Lian, J. B., M. D. Benson, M. Skinner, and A. S. Cohen. 1975. A 25,000 molecular weight protein constituent of human amyloid fibrils related to amyloid protein AA. Arch. Biochem. Biophys. 171: 197-205.

18. Skinner, M., E. S. Cathcart, A. S. Cohen, and M. D. Benson. 1974. Isolation and identification by sequence analysis of experimentally induced guinea pig amyloid fibrils. J. Exp. Med. 140: 871-876.

19. Anders, R. F., K. Nordstoga, J. B. Natvig, and G. Husby. 1976. Amyloid-related serum protein SAA in endotoxininduced amyloidosis of the mink. J. Exp. Med. 143: 678683.

20. Shirahama, T., and A. S. Cohen. 1975. Intralysosomal formation of amyloid fibrils. Am. J. Pathol. 81: 101-116.

21. Scheinberg, M. A., and E. S. Cathcart. 1974. Caseininduced experimental amyloidosis. III. Response to mitogens, allogeneic cells, and graft-versus-host reactions in the murine model. Immunology 27: 953-963.

22. Scheinberg, M. A., and E. S. Cathcart. 1976. Caseininduced experimental amyloidosis. VI. A pathogenetic role for $\mathrm{B}$ cells in the murine model. Immunology. 31: $443-453$.

23. Yonkosky, D., E. S. Cathcart, and M. Scheinberg. 1976. B-cell activation and macrophage dysfunction in casein-induced experimental amyloidosis. Arthritis Rheum. 19: 831. (Abstr.) 